\title{
Actualización del ranchero como tipo popular en Los fuereños, de José Tomás de Cuéllar
}

Actualization of the ranchero as a popular type in José Tomás de Cuéllar's Los fuereños

\author{
Claudia Alejandra Colosio García \\ ORCID: 0000-0001-5379-0630 \\ El Colegio de San Luis, México \\ claudiacolosiog@gmail.com
}

\section{Resumen:}

Los fuereños (1883) de José Tomás de Cuéllar actualiza la figura del tipo popular del ranchero. Contrasta la idealización del costumbrismo, reflejada en las primeras décadas del siglo XIX y registrada en el compendio Los mexicanos pintados por sí mismos (1854-1855), con el realismo representado en el choque de su ingenuidad ante los usos de la ciudad mexicana moderna. En este artículo se realiza una interpretación del personaje en los textos mencionados. El objetivo consiste en determinar cómo el contraste que plantea Cuéllar entre la mirada sublimada de antaño y la risible de su contexto formula su crítica al desarrollo artificial y vicioso de la capital que consume a los provincianos, incapaces de entender sus códigos. La metodología gira en torno al análisis comparativo e interartístico (relación texto-litografía) de las obras. Dicho enfoque, extensivo a otras novelas ilustradas del periodo, permite leer la obra integralmente como un doble discurso, complementario entre sí. Examino la función de los cambios idiosincráticos, textuales e iconográficos, reflejados en la configuración de Gumesindo, el ranchero en la novela corta de Cuéllar, en relación con el paradigma anterior. Tales cambios permiten al tipo popular obtener cierta autonomía en sus decisiones, y estas, al conducirlo a los bajos fondos, 
conceden a la voz narrativa el hilo argumental para completar su diatriba social.

\section{Palabras clave:}

José Tomás de Cuéllar, Los fuereños, narrativa mexicana siglo XIX, litografía mexicana siglo XIX.

\section{Abstract:}

Los fuereños (1883) by José Tomás de Cuéllar updates the figure of the popular type of the ranchero. Contrasts the idealization of costumbrism reflected in the first decades of the 19th century, recorded in the compendium Los mexicanos pintados por si mismos (1854-1855), with the realism reflected in the clash between its naivety and the customs of the modern Mexican city. This article interprets the character in the texts previously mentioned, with the objective of determining how Cuéllar's contrast the exalted gaze of yesteryear and the laughable one of its context to formulate its critique of the artificial and vicious development of the capital that consumes the provincials, unable to understand their codes. The methodology followed revolves around the comparative and interartistic analysis (text-lithography relationship) of the works. This approach, extended to other illustrated novels of the period, makes it possible to read the work in its entirety as a double discourse, complementary to each other. I examine the role of the ideological, textual and iconographic changes, reflected in the configuration of Gumesindo, the ranchero in the Cuéllar novel, in relation to the previous paradigm. Such changes allow the popular type to obtain a certain autonomy in its decisions, and these, by leading it to the underworld, give the narrative voice the thread of argument to complete its social diatribe.

Keywords:

José Tomás de Cuéllar, Los fuereños, 19th-century Mexican Narrative, 19th-century Mexican Litography

DOI: https://doi.org/10.36798/critlit.vi20.321

Recibido: 29 de octubre de 2019

Aceptado: 27 de febrero de 2020 


\section{Introducción}

En las colecciones de tipos populares ${ }^{1}$ aparecieron (literaria y plásticamente) los espacios y actores sociales que aún hoy identifican a México y al mexicano. Hacia los últimos veinte años del siglo XIX, en un estado de supuesta estabilidad artística bajo el régimen porfirista, la relación texto-imagen - consolidada ya tecnológica y culturalmente- siguió al servicio de escritores, dibujantes y editores, quienes siguieron leyendo la sociedad desde esta doble óptica.

En el presente artículo me propongo explorar las relaciones del discurso interartístico en la novela corta Los fuereños ${ }^{2}$ de José Tomás de Cuéllar (1830-1894), también conocido por el pseudónimo de Facundo. La novela se publicó originalmente en los meses de marzo, abril, mayo y junio de 1883 en el periódico mexicano El Diario del Hogar y luego con variantes en España como parte de la segunda época de la colección La linterna mágica en 1890. El ejemplar correspondiente a esta obra también incluyó La Noche Buena, otra novela de 1883 y del mismo diario. Como se verá a continuación, Los fuereños permite su lectura bajo la óptica de los artículos y las no-

${ }^{1}$ Acudo a la definición del género de tipos propuesta por María Esther Pérez Salas: "consiste en un relato sobre un personaje determinado que presenta cierta peculiaridad, ya sea por su oficio, su forma de vestir o de hablar o por el papel que desempeña dentro de la sociedad . . . la peculiaridad del personaje podía ser manejada desde ángulos diferentes, ya fuera moralista, satírico, folklórico o nacionalista" (Pérez Salas, Costumbrismo... 53).

${ }^{2}$ Todas las referencias textuales a esta obra pertenecen a: Cuéllar, José Tomás de. Los fuereños. Obras IV. Narrativa IV. Novelas cortas, UNAM, 2012. Las ilustraciones proceden tanto de esta edición, como de la Colección Digital de la Universidad Autónoma de Nuevo León y de la edición publicada por la Biblioteca Digital Hispánica. Las tres fuentes, a su vez, recuperaron las imágenes del volumen Los fuereños y La Noche Buena de 1890, editado en Santander por la Imprenta y Litografía de "El Atlántico"..

${ }^{3}$ Según Ana Laura Zavala: "Los fuereños no se proyectó como parte de una serie ni se distribuyó en fascículos para su venta semanal e independiente, sino que sus catorce entregas se insertaron en las heterogéneas columnas del periódico de Filomeno Mata, El Diario del Hogar (1883)" ("Espejismos de la modernidad...” 12). 
velas costumbristas que circularon en revistas literarias durante las décadas de 1840 y $1850^{4}$, pese a su distancia temporal con la poética de este periodo, con la diferencia de que la obra de Cuéllar presenta un cuadro de costumbres en movimiento.

El presente artículo definirá la perspectiva del tipo popular del ranchero empleada por Cuéllar para designar y configurar el personaje de Gumesindo en Los fuereños, la cual corresponde a una actualización de la figura del ranchero, figura central de la provincia de México, respecto a la manejada con anterioridad en la cultura escrita y visual mexicana. Para ello, compararé la visión de Cuéllar con la de otro momento clave de la centuria decimonona: Los mexicanos pintados por sí mismos. Tipos y costumbres nacionales (1854-1855), colección que sintetiza el interés de 1850 por la definición de los elementos tipificantes del acervo sociocultural del país letrado. El contraste y la parodia que Cuéllar sugiere con este personaje y otros de la novela tiene la finalidad de examinar la superficialidad y vicio que se expanden sobre la capital mexicana moderna. El tratamiento que recibe el ranchero refleja la oposición moral e idiosincrática entre el campo y la ciudad. Los atributos que definían al tipo a mediados de siglo como un hombre firme, directo, práctico y responsable, conectado de forma casi sublime con la tierra y estéticamente distinguible por su vestimenta particular, en esta novela son em-

${ }^{4}$ Cfr. María Esther Pérez Salas, Costumbrismo y litografía en México 194. La preocupación por fijar y difundir las costumbres "nacionales" por medio de descripciones pintorescas y discursos didácticos-moralizantes se estableció en la década de 1840 como modelo para las publicaciones del momento y posteriores, como Los mexicanos pintados por si mismos en 1854 . No obstante, aunque se buscaba la originalidad visual se mantuvo la apertura de tomar ejemplos de la producción gráfica española. Tal perspectiva cambiaría paulatinamente conforme a los cambios tecnológicos y sociales hacia el final del siglo, cuyo ejemplo puede considerarse la obra aquí estudiada.

${ }^{5}$ A partir de aquí, todas las referencias textuales a esta obra pertenecerán a: Frías y Soto, Hilarión, et al. Los mexicanos pintados por sí mismos. Tipos y costumbres nacionales. Miguel Ángel Porrúa, 2011. La litografía aquí utilizada, por su parte, proviene de la Colección Digital de la Universidad Autónoma de Nuevo León, correspondiente a la edición de la imprenta de Manuel Murguía en 1855. 
pleados como elementos clave para desacralizarlo, pues la llaneza e ingenuidad del personaje lo exponen a los ardides maliciosos de la capital.

La revisión cronológica de las obras permitirá establecer la imagen que para 1880 se había establecido del ranchero en el imaginario lector, mismas cualidades que ahora la obra de Cuéllar presenta como risibles y degradantes con el fin de advertir los problemas del advenimiento forzado de la modernidad. Para la novela, esta ha sido malentendida por la sociedad, que en vez de emplearla como vehículo de progreso ha permitido la instalación de infraestructura defectuosa y la proliferación de actitudes moralmente cuestionables.

Iniciaré el análisis con la presentación individual tanto de la colección de tipos como de la nouvelle y sus respectivos vínculos con las ilustraciones, para luego contraponer sus perspectivas. Con ello ilustraré la dinámica del personaje en ambos materiales para demostrar que Gumesindo, el ranchero de Losfuereños, es una actualización paródica respecto a la representación canónica del tipo popular. La función del efecto desacralizador y hasta cierto punto, caricaturesco, podría leerse como alegoría de la inserción artificial y hasta torpe del mexicano ante los avances de infraestructura urbana europea implementados en México, que no solo parecen ajenos al contexto particular del tipo, sino que además han sido mal adaptados a la realidad del país.

En la novela, Gumesindo es el único personaje que aparece en las tres ilustraciones que acompañan la obra. Para establecer el esquema comparativo entre la colección de tipos y la novela corta finisecular recurriré al estudio del conjunto de relaciones entre los medios artísticos visual y textual, empleando la comparación como medio para entender el diálogo que, en ambos casos, esclarece el matiz de solemnidad, orgullo, humor o degradación del personaje. El cambio de perspectiva entre uno y otro periodo se apoya de este vínculo entre artes:

Necesidad o argumento comercial según los editores, para casi todos los novelistas realistas supuso el acompañamiento de imágenes una intrusión, una competencia con el imagi- 
nario propiamente literario ya que la imagen gráfica no se contenta con representar sino que «hace creer»: casi una usurpación de una función tradicional de la literatura. (Botrel 224)

La importancia que reconoce Botrel en el espectro de las publicaciones de la segunda mitad de la centuria decimonónica española es extensible a Latinoamérica en cuanto al refuerzo didáctico e ideológico que la imagen constituyó para los lectores de su tiempo, quienes podían reconstruir visualmente la imagen literaria propuesta en la narración. De igual manera, concuerdo con William John Thomas Mitchell, cuya reflexión sobre los estudios de objetos culturales verbales y visuales es aplicable a las obras aquí estudiadas. La pertinencia de la revisión simultánea de los discursos artísticos visual y textual se debe a que los dos libros se concibieron materialmente como estructuras conjuntas que pueden responder a las convenciones dominantes que gobiernan la relación de la experiencia visual y la verbal (Mitchell 85).

Los mexicanos pintados por sí mismos. Tipos y costumbres nacionales es un compendio de artículos literarios y estampas litográficas. Las plumas de Hilarión Frías y Soto, Niceto de Zamacois, Juan de Dios Arias, José María Rivera, Pantaleón Tovar e Ignacio Ramírez sintetizan las convenciones formales y estilísticas del género de las colecciones de tipos. El propósito de cada texto es "presentar" al público una serie de actores sociales de la cotidianidad mexicana (capitalina, en la mayoría de los casos), quienes ejercen diversos oficios que les atribuyen comportamientos y costumbres determinadas supuestamente por su ambiente social de origen. Los personajes no fueron inventados por los autores, sino recuperados de la tradición popular porque efectivamente pertenecían al espectro laboral.

Los mexicanos pintados por sí mismos... fue publicado por entregas en el periódico El Siglo XIX desde octubre de 1854, antes de aparecer como volumen en 1855 en la imprenta de Manuel Murguía. Presenta treinta y tres tipos a través de escenas costumbristas ${ }^{6}$ que

6 "uno de los subgéneros del costumbrismo que relataba una breve historia 
incorporan extractos de diálogos teatrales y versos en sus narraciones. Está emparentada con una amplia tradición visual y textual cuyo afán de categorizar oficios y actores sociales propició textos con la etiqueta "por sí mismos" en Inglaterra, Francia, España y Cuba, además del modelo mexicano. Según cada nación, los personajes respondían a sus paradigmas del comportamiento social. En este contexto, la relación interartística con la plástica mediante el grabado y la litografía reforzó la formulación estética, literaria e identitaria del naciente país desde los primeros intentos de publicaciones literarias y costumbristas ilustradas, pues mientras el artículo se dedicaba principalmente a la descripción ética del personaje, sus motivaciones y lenguaje — aunque también sugerían un esbozo físico-, la imagen ofrecía el retrato visual.

Los protagonistas de Los fuereños se presentan como una propuesta de tipos populares modernos, que reside en la definición sistematizada de su apariencia y mentalidad. El argumento de la obra tiene como eje central las peripecias de la familia Ramírez, terratenientes acaudalados de provincia poco habituados a la vida urbana, durante su visita a la Ciudad de México. Cada integrante de la familia se deja llevar por las novedades que ofrece la capital y, por el exceso de confianza que ingenuamente depositan en ella y sus habitantes, cada uno padece una desgracia moral y social diferente. Don Trinidad y Doña Candelaria sufrieron humillaciones públicas y terminan temporalmente en la comisaría, su hijo Gumesindo perdió dinero y salud en un burdel, y las hijas fueron seducidas por jóvenes citadinos maliciosos. El choque de su estilo de vida, códigos de comportamiento e ideas preconcebidas sobre la vida urbana lleva a los personajes del deslumbramiento inicial a la degradación moral, física y financiera, aunque pasando brevemente por momentos deleitantes al ver cumplidas sus fantasías, pues su inocencia fue aprovechada por los capitalinos más abusivos, quienes propiciaron su declive.

que servía de hilo conductor para describir el modo de ser de los personajes, en especial el del tipo en cuestión, así como el ambiente en que trabajaba, su indumentaria y su manera de hablar" (Pérez Salas, Costumbrismo...289). 
El origen de la familia no responde a un sitio particular del interior del país, ni se autodefinen por un gentilicio, sino que sus miembros se configuran respecto a una concepción genérica del provinciano. Incluso el narrador omnisciente y las voces de otros personajes los llaman por la categoría tipológica en la que se encasillarían, simplemente fuereños. Entre ellos, el ranchero, cuya representación visual y literaria se basa en su traje pintoresco, lenguaje sin miramientos y recelo de los citadinos, resalta porque en contraste con estos es un hombre confiado en demasía, curioso y torpe en los usos de la capital — pero deseoso de aprenderlos-. Lo anterior es congruente con las necesidades discursivas del dibujo social propuesto por Cuéllar con el fin de ofrecer una lección didáctica. Critica la transición artificial hacia una sociedad moderna que, ante los cambios en su paradigma de comportamiento, reniega y ridiculiza sus "verdaderas" (o tradicionales) costumbres. A su vez, algunas de las representaciones culturales fijadas por la tradición para describir a la población nacional se han quedado anquilosadas en el pasado y serán otras figuras menos morales quienes definan al mexicano del momento.

\section{El ranchero entre el medio siglo y los albores finiseculares}

Antes de analizar al ranchero, propongo la siguiente clasificación general para el resto de los personajes. Los fuereños: Don Trinidad y Doña Candelaria, son los padres absortos ante las diferencias entre su pueblo y la gran ciudad, representan el contraste entre uno y otro ambiente; las pollas: Clara y Guadalupe, las hijas jovencitas de la pareja mencionada que adoptan normas de urbanidad francesa y quieren relucir en la capital con sueños provenientes de lecturas novelescas; el ranchero: Gumesindo, es el hijo dedicado a los quehaceres del campo y curioso ante los placeres que la capital le ofrece; los lagartijos: Manuel, Carlos, Nito, Trujillo y Pepe, personajes ajenos a la familia que guían a Gumesindo por la cartografía dionisiaca de la ciudad, retratos emparentados con los pollos, ya pertenecientes al 
mundo literario de Cuéllar. ${ }^{7}$ De igual modo, la obra expone el modelo de los criados, que entre los personajes secundarios, son los que mayores implicaciones tienen en el desarrollo de la trama por sus complicidades con los jóvenes; son el vínculo entre pollos, lagartijos, fuereños y el mundo exterior. ${ }^{8}$ Dejo fuera de esta clasificación, deliberadamente, a Gutiérrez, porque constituye la óptica interna del narrador y su rol es presentar la capital a la familia recién llegada, explicar su funcionamiento y criticar sus errores. ${ }^{9}$ Resalto también a Nicolás, otro hijo del matrimonio que, si bien no aparece en la narración, es referido por sus padres como un joven campirano que llegó a la ciudad para ser estudiante y que ahora rechaza su procedencia rural en favor de preferir el ambiente citadino. Sus padres atribuyen su nueva actitud a la mala influencia de la formación académica adquirida.

Cabe resaltar que la diatriba mediante el uso de personajes tipo fue una constante en la narrativa de Cuéllar quien, bajo el nombre de La linterna mágica, ${ }^{10}$ construyó un universo literario de relaciones

7 “En el México de la segunda mitad del siglo XIX, los 'pollos’ personificaban a un importante sector de la juventud mexicana marcado por la ociosidad, el vicio y las apariencias, así como la falta de nacionalismo, manifiesto en el afrancesamiento de sus costumbres" (Zavala, "Más allá de la linterna mágica..." 112).

${ }^{8}$ José Tomás de Cuéllar ofrece una catalogación completa de las características y hábitos de los pollos en la novela corta Ensalada de pollos (1869-1870).

9 Su función "es traducir para los fuereños todo aquello que contemplan; más aún, especie de álter ego de Facundo, representa la mirada crítica, encargada de hacer visible la principal paradoja de la incipiente modernidad porfiriana: el progreso científico y tecnológico que ha transformado de manera tan evidente el espacio citadino (ferrocarriles, telégrafo, teléfono, luz eléctrica, etcétera), no guarda relación alguna con los usos y costumbres de sus habitantes" (Zavala, "Espejismos..." 15).

${ }^{10}$ De acuerdo a la prensa finisecular, además de apelar al éxito editorial de Cuéllar, la reedición española de La Linterna Mágica también se concibe como un proyecto en el que participó el autor directamente para reordenar y presentar su literatura con el fin didáctico de dar a conocer las condiciones de la sociedad y combatir sus vicios. Así lo deja ver el "Boletín bibliográfico" del periódico mexicano El Nacional el 30 de mayo de 1889: "Los editores dicen en su prospecto lo siguiente: 
intertextuales donde participan los tipos populares más problemáticos, como los ya mencionados criados y pollos, u otros como las jamonas (mujeres coquetas de mediana edad, avejentadas en la época), para evidenciarlos como partícipes de los problemas sociales más allá del nivel ficcional, en el espacio social mexicano. La novela confirmará que la ciudad se ha vuelto una entidad totalizadora, basada en espejismos de modernidad, como lo define Ana Laura Zavala, que engulle a quienes no comulgan con sus convenciones:

[L]e mostró [a los lectores] los enormes riesgos económicos y sociales de imponer en un país como México, inacabado, todavía en construcción, un sistema capitalista basado únicamente en los valores de cambio, en el progreso material, en las apariencias. Al hacer este "retrato" el autor actualizó en Los fuereños la preocupación que insufló su amplio ejercicio escritural: la urgencia de definir el rostro de la nación, a partir de la configuración modélica de los espacios y de los cuerpos que dieran existencia a ésta . . (Zavala, "Espejismos..." 2627).

«Esta publicación tiene por objeto reunir en una colección las obras completas del eminente poeta y distinguido novelista Sr. D. José Tomás de Cuéllar, inédita muchas, diseminadas otras en multitud de periódicos de diferentes épocas, y en tomos cuyas ediciones se han agotado completamente. Tal empresa no encierra solamente una cuestión bibliográfica, sino que prestará positivo servicio a la literatura nacional y a la moral social, puesto que Cuéllar no solo es nuestro primer escritor de costumbres, sino que la tendencia moral que predomina en todo lo que escribe llena el alto y noble objeto de la sana literatura, presentando cuadros fidelísimos de nuestras propias costumbres, con el estilo jovial, fácil y chispeante que le es peculiar, inculando siempre serias y trascendentales ideas de la moral más pura.»

Tratándose de una colección de obras de un escritor mexicano, que han obtenido grande aceptación, no dudamos que obtendrán una numerosa clientela, y más por la circunstancia de haber establecido suscripciones muy cómodas para los abonados" (2). 
A pesar de que los personajes manifiestan deseos y tratan, en algunos casos, de salir de su condición de fuereños, sus decisiones erróneas responden a la oposición indisoluble entre los valores de uno y otro espacio. No obstante, la vida rural tampoco se consagra como el modelo moral definitivo para la sociedad mexicana; pues, aunque la ciudad es pícara y ociosa, los recién llegados son directos y confiados, pero también torpes y pretenciosos. En la óptica narrativa, la ciudad no castiga la bondad, sino la ingenuidad, al contrario de lo que hicieron las colecciones de tipos de mediados de siglo con la representación del hombre campirano.

En el compendio Los mexicanos pintados por sí mismos, cada texto se acompaña de una litografía, dibujada ya sea por Hesiquio Iriarte ${ }^{11}$ o por Andrés Campillo ${ }^{12}$, que muestra un retrato del personaje inserto en un espacio físico conforme a su condición social y rodeado de objetos característicos de su labor. El lector reconocería oficios comunes de la ciudad como "El aguador", "El maestro de escuela" o "El evangelista". Su publicación coincide con el último periodo presidencial de Antonio López de Santa Anna, los años posteriores

${ }^{11}$ Según Fróes Da Fonseca, "Hesiquio Iriarte y Zuñiga (1824-1903) . . . trabajó en el taller de Manuel Murguía, y sus litografías fueron de varios géneros, incluyendo la ilustración científica, la estampa religiosa, el género de batalla, y los retratos civiles. En su obra litográfica se destacó la de tipo costumbrista, presentando escenas de la vida cotidiana en la ciudad de México y en el campo. Ilustró artículos en periódicos como El Museo Mexicano, El Mosaico Mexicano y El Almacén Universal. Hasta 1855 firmaba sus obras como 'Litografía de Iriarte y Compañía'. Sus litografías también estaban en El Gallo Pitagórico, en El Parnaso Mexicano, y en revistas culturales como El Renacimiento, y El Artista. Integró el grupo que fundó la Revista Científica y Literaria, creada en 1845. Participó de obras científicas como la Memoria de los trabajos de la Comisión Cientifica de Pachuca de 1865. Tiene inúmeras litografías suyas publicadas en la obra Los mexicanos pintados por sí mismos. Tipos y costumbres nacionales, por varios autores" (47; cursivas mías).

${ }^{12}$ La breve noticia biográfica de Andrés Campillo, compuesta por datos dispersos, menciona que fue un grabador italiano, hermano de otra figura destacada de la litografía mexicana de los años de 1850, Julián Campillo, quien participó en 1885 en la ilustración de México y sus Alrededores. Colección de Vistas, Trajes y Monumentos. "Ellos se encargaron de producir las primeras imágenes costumbristas del estereotipo mexicano" (Arellano 372). 
al final de la guerra contra Estados Unidos (1846-1848) y la pérdida de grandes extensiones de territorio nacional. En tales circunstancias, la obra se configura como un escaparate de marco intelectual para difundir una imagen formulada a partir de los trajes y costumbres etiquetados como "nacionales", en un intento de unificación por la continua inestabilidad política y económica. Hilarión Frías y Soto aprovecha el primer artículo de la obra, "El Aguador", para establecer los alcances literarios del proyecto:

Lo que te atañe saber es que tú, como mexicano, tienes que dar al público tus costumbres, tus hábitos, tus vicios, tus cualidades, todo, en fin, lo que te es peculiar o propio, tienes que contárselo al mundo entero: hasta una estampa se ha hecho donde estás pintiparado, tal como eres, para que todos te conozcan. Ahora bien; como tú no puedes escribir o hacer tu retrato, yo me he apropiado esa obligación pero necesito que me des datos, que me informes de todo lo que te concierna, para poder escribir tu artículo e imprimirle. (8)

El objetivo se basa en trazar las características físicas y psicológicas de los personajes a partir de "conversar" con ellos para construir sus perfiles con mayor verosimilitud. ${ }^{13} \mathrm{El}$ intelectual considera que tiene la oportunidad de asir la cultura popular para ofrecerla al público curioso. A través del humor se retratan tipos de la incipiente sociedad urbana en la capital, a excepción del ranchero y el arriero, de origen rural, y otros que pudieran encontrarse en los dos ámbitos. ${ }^{14}$ La distancia temporal de casi treinta años entre Los fuerenos y este volumen evidenciará el proceso de cambio de perspectiva.

${ }^{13}$ Cfr. Zavala Díaz, Ana Laura "Espejismos de la modernidad: la Ciudad de México en Los fuereños de José Tomás de Cuéllar”. Literatura Mexicana, vol. XXVII, no. 2, 2016, p.12.

${ }^{14}$ Cfr. Pérez Salas Cantú, María Esther. "Primeros intentos por definir los tipos mexicanos en la primera mitad del siglo XIX". Histoire(s) de l'Amérique latine, vol. 1, 2005, p. 7. Asimismo, cabe añadir a su clasificación nacional "El Evangelista", quien se dedicaba a leer y escribir cartas y otros documentos por pedido en la Plaza de Santo Domingo, en la Ciudad de México. 
"El ranchero", artículo de José María Rivera ${ }^{15}$ fechado en junio de 1855, se presenta como una crónica de su experiencia como huésped de la familia de Don Alonso, quien aceptó ser tomado como ejemplo para describir su habla y sus costumbres. El texto no enlista taxonómicamente las características físicas y psicológicas del personaje, sino que las reconstruye a través del contraste entre el propio estilo de vida urbanizado de Rivera y el de sus anfitriones mediante el artificio narrativo.

No sé la hora que es. Olvidé dar cuerda a mi reloj; pero según las ganas que tengo de dormir creo que la condenada guía, que ha comenzado a ser mi mala estrella, ha surgido en el horizonte antes de tiempo.

- ¿Siñor amo?

- ¡No lo digo! ¿Qué hay, Pancho?

-Nos coge el día, siñor.

- Hombre, me parece que aún es muy temprano.

-Ojalá, siñor, pero dende que aquel gallo ha cantado ya por tres ocasiones.

— ¡Demonio de muchacho! ¡qué orejas tiene...! Yo no tengo gallo, ni creo que lo haya en las vecindades. (Rivera 362)

Madrugar al canto del gallo como Pancho, hijo de Don Alonso, le parece al narrador una práctica incómoda y distante, pues está acostumbrado a desvelarse en la escritura, característica asociada a su

${ }^{15}$ A propósito de este escritor, Webster Henestrosa apunta que "[s]olo unas cuantas noticias se tienen de José María Rivera, y alguna, confusa. La fecha que se da como de su nacimiento, 1807, no se sabe a punto cierto si se refiere a él o algunos de los otros José María Rivera que fueron contemporáneos suyos: un sacerdote y un editor, quizás los dos poblanos. Ninguno de los autores de historia de la literatura mexicana lo aluden. Tampoco los diccionarios biográficos. Con frecuencia se le confunde con José María Ramírez. . . José María Rivera escribió, ciertamente, siete de los retratos de Los mexicanos pintados por sí mismos; otro, El Poetrastro, lo firmó con [Hilarión] Frías y Soto, con el anagrama Feva Irisarri” (559-560). 
propia concepción del intelectual, cuyos pensamientos brotan en la ensoñación nocturna. En cambio, Pancho se rige por las señales de la naturaleza, que resaltan en él los atributos que definen a todo su modelo, como la fuerza, la generosidad y la honestidad. Según Rivera:

Don Alonso, verdadero tipo de esta gente, es un hombre laborioso, franco, urbano a su modo, filántropo sin haber pertenecido a ninguna sociedad de beneficencia, y sobre todo, es ingenuo, cándido y sencillo a toda prueba. Es uno de aquellos hombres que le dicen a usted con mayor frescura: Beba, amito, hasta que se llene: coma su mercé cuanto quera que aquí no tenemos hambre; y en suma, no tuvo embarazo para pedir la novia de su hijo Pancho, por medio de una carta, en la cual le decía al padre de la pretensa: El bestia de mi hijo ha dado en la gran tontera de quererse casar con la bija de usté, Juanilla la aguanosa. Y sin embargo, lector, don Alonso jamás pensará ofenderte con semejantes frases, que por cierto no expresan más que la verdad, si bien las examinas. (369)

Los rancheros se expresan con franqueza dan o reciben todo lo posible dentro del equilibrio de su entorno. La procedencia rural define la genealogía del tipo. Su dominio del campo no solo se basa en el trabajo físico sino en la posesión de la tierra; la compenetración con la naturaleza se da desde el sentido de la propiedad.

Si bien esta descripción no corresponde al estrato social de Gumesindo, sí comparte elementos como la descripción inicial, dada en la novela corta a partir del comentario de Don Trinidad:

-Éste es ranchero. A éste quítelo usted de lazar y andar a caballo y no sabe hacer nada. No es para los estudios.

-A él le gusta el campo, agregó Doña Candelaria. (177)

En el texto de José María Rivera, de igual forma se menciona el barbear un becerro, actividad que consiste en "arrojarse sobre el animal, asiéndolo de la oreja derecha con una mano, y con la otra de la barba; en seguida, se hace un violento esfuerzo, se tuerce el cuello de la víctima, y se le echa por tierra en un abrir y cerrar de ojos" (371); 
con lo cual el brío y la fuerza física se mantienen como características - y virtudes - reconocidas en el personaje por las dos obras.

Rivera, quien constantemente compara el cuadro que contempla con su realidad cotidiana, recalca que,

[a]hora, el que fuere curioso haga una especie de balance de unos [las usanzas rancheras] y otros goces [diversiones de la capital], y hallará: que por cada ranchero que espicha a causa de sus diversiones bárbaras, hay mil gentes ilustradas que perecen a manos de sus delicias cortesanas. (370)

En este ejercicio metonímico, el citadino encarna la sumisión al vicio; mientras que el ranchero, la virtud. Para Don Trinidad, padre de Gumesindo, la apología a sus cualidades también justifica su falta de formación académica desde la creencia de que la prioridad es formar hijos diestros en las labores del campo, pues así tendrán un futuro digno y provechoso:

Yo quiero a mis hijos rancheros y no catrines. Y así lo ha hecho, señor Gutiérrez, y se va saliendo con la suya de hacerlos hombres honrados. Los muchachos son trabajadores, y las labores de mi compadre se pueden ver; da gusto ver sus campos y sus animales. (Cuéllar 178)

En este punto coinciden nuevamente las dos publicaciones, pues la formación del ranchero se basa esencialmente en el cuidado de la tierra y obediencia familiar. Su valor reside en la capacidad para moldear un patrimonio con esfuerzo, cuya prosperidad sea visible en cuanto al dominio y manejo de la tierra. Según David Skerritt Gardner:

Ligada a la autoridad está la educación, que también se considera algo inútil, no enseña habilidades prácticas para el desempeño de las labores del rancho. La enseñanza más bien tiene dos pilares que están entendidos como internos: la iglesia y el hogar. El catequismo es especialmente importante ya que éste precisamente apuntala la centralidad de la familia y la obediencia. (140) 
La ignorancia es otro factor definidor del personaje y, simultáneamente, base del declive de Gumesindo en la ciudad. Este rasgo, al que José María Rivera ya hacía alusión en su artículo, ${ }^{16}$ se confunde con la inocencia de quien está acostumbrado al trato directo - $\mathrm{y}$ sincero- y a creer lo que ve, incluso antes de saber los códigos de un ambiente nuevo. Rivera, después de conocer al ranchero, se dio cuenta de que nadie podría ser más feliz en el mundo que él (369). Esta configuración del ranchero se mantendría en los años posteriores, pues siguió apareciendo en otros espacios editoriales donde el personaje seguía como epítome de las cualidades intrínsecas del hombre mexicano. ${ }^{17}$ Por el contrario, en el momento de la escritura de Cuéllar, esta cláusula ya solo es aplicable a su propio entorno;

${ }^{16}$ En la primera conversación con Rivera, Don Alonso se resiste a la entrevista y al proyecto de escritura de aquel por la desconfianza de la visión citadina que se tiene de los hombres de campo: "iAcabara su mercé de reventar! Hasta las últimas palabras no caí en la cuenta de lo que su mercé quere hacer conmigo. ¡Pues! usté solicita darles a los de la suidá el gusto de que se rían del payo, del lechero, del boca e palo, como ustedes nos llaman, ¿no es verdad amito?” (Rivera 360).

${ }^{17}$ Destaco su mención en el artículo "Trajes mexicanos" que Niceto de Zamacois incluyó en el álbum México y sus alrededores (1855-1856), cuyo tono discursivo es similar al retrato ya referido y se acompañó con su respectiva litografía: "[Los rancheros] son los que forman verdaderamente el tipo nacional, tanto por las costumbres originales que los distinguen, cuanto por el agradable y pintoresco traje que visten. / El ranchero mexicano es hombre franco, sencillo, valiente y hospitalario: sus costumbres son puras, sus necesidades pocas, su ambición ninguna, su diversión favorita el caballo, su arma temible el lazo, y a nadie cede en nobles sentimientos. Promuévase alguna conversación de un asunto difícil, y después de manifestar un talento natural y despejado, concluirá diciendo con franqueza, que teme haberse equivocado, y añadirá luego estas palabras, que relevan su decidida afición a la vida del campo. ... / La diversión favorita de los rancheros es, cuando tratan de celebrar alguna boda u otro acontecimiento notable, el travesear con los animales, como ellos dicen. ... / Examinemos ahora el traje del ranchero, de ese hombre que parece que le han clavado a la silla del caballo, según lo firme y bien sentado que va en ella. ¿Qué vestido más propio para montar sobre un arrotante alazán que el suyo? Los extranjeros lo miran con interés y gusto, y aplauden entre sí la feliz idea del que lo inventó, como la aplaudí yo, cuando al venir de España pude admirar tan pintoresco traje" (30). 
fuera de él es un forastero curioso. La seducción de los placeres urbanos es el punto de quiebre para este personaje.

El proceso de cambio en Gumesindo se refleja desde su primera experiencia individual citadina: la visita a la $1^{\text {a }}$ calle de Plateros, donde el narrador reafirmará cómo el personaje resalta entre otros jóvenes por su vestimenta (factor decisivo para la construcción de un tipo, pues, ante los lectores, la representación visual lo define mejor que la descripción literaria):

Gumesindo descollaba, entre los pollos vestidos de negro, por su sombrero canelo adornado con anchos galones de oro y por su pantalón de montar ajustado a la pierna. Gumesindo peinaba los veintiuno, era buen mozo, de grandes ojos negros y estaba en esos momentos en que el hombre piensa sólo en dos cosas: en su persona y en el amor. (Cuéllar 198)

El lector conocerá su adaptación por los comentarios de los demás personajes o las mediaciones del narrador. La voz que conoceremos de Gumesindo no será la de quien se sorprende ante los cambios - se siente seguro gracias a los consejos previos que recibió en su pueblo antes de partir - sino la de sus propios deseos e ilusiones, rasgo de individualismo que rompe con la esquematización fija del tipo, pero que igualmente lo lleva a los bajos fondos. Dicho retrato de un ranchero es localizable en otro momento de la narrativa del autor. En Las gentes que son asi (Perfiles de hoy) (1872) el personaje de Alberto, un joven que se transforma en bandido con el nombre de José María Gómez, representa su conversión cuando adquiere la indumentaria de un ranchero o charrito coronada por un sombrero llamativo:

Lo primero que hizo Gómez, que así le llamaremos en lo sucesivo, fue comprar el sombrero de más costo que encontró en las tiendas. / El sombrero bordado de plata y oro es, en el país, la introducción indispensable al bien parecer . . . / Gómez era a la sazón un mozo presentable, era gran jinete, y su color bronceado y sus maneras no carecían de atractivo para 
la mujer que fuera capaz, como lo son muchas, de hacer de un charrito el bello ideal de sus ensueños. (Las gentes 19)

La similitud en el tratamiento de Gómez y Gumesindo reformula a través de diferentes obras la situación social de los rancheros, para lo cual Cuéllar empleó los referentes de la imaginería social decimonónica (Ramos 28). Lo anterior indica que, si bien el ranchero de Los fuereños no es un personaje malvado ni comete crímenes conscientemente, hay una pretensión por parte de la figura autoral de desacralizarlo como referente de virtudes al predisponerlo al vicio, lo que a su vez podría originarse en la conciencia de que su figura ha perdido vigencia como representación nacional en el marco de la modernidad. El desconocimiento de los códigos para relacionarse en la ciudad permite que Gumesindo confunda una meretriz finamente ataviada con una señora de alcurnia, a la que corteja con cuantiosos regalos (Zavala, "Espejismo..." 19-20). La diferencia entre el estado inicial de Gumesindo y el desafortunado final de su aventura se resume y reafirma en la novela por medio de las imágenes que acompañan el texto.

\section{Lecturas visuales del tipo popular}

En este contexto, la relación entre Los mexicanos pintados por sí mismos y Los fuereños con sus ilustraciones complejiza la interpretación del retrato. En la relación establecida entre el texto y la imagen en el espectro editorial hispanoamericano del siglo XIX, este segundo elemento no solo decora el folio, sino que también complementa, imita o reafirma el contenido (Pas 74). Por lo cual, antes de asentar el vínculo cronológico de la perspectiva del ranchero en uno y otro periodo, es necesario establecer primero cuál es el vínculo entre las obras escritas y las pictóricas por separado. Visualmente los tipos de ambas obras también comparten elementos, como el sarape y los pantalones abotonados; otros se modernizan, como el tránsito del pantalón acampanado al tubular y el diseño del sombrero jarana que pasó de copa media a copa alta (que en Los fuereños deja suficiente espacio para el monograma “GR”). 
Las ilustraciones, más que un elemento paratextual, como Genette define a los elementos accesorios de una obra literaria como el título, subtítulo, epílogo, entre otros (11), es la síntesis física del personaje y la primera representación cultural que registra un lector en su memoria, aun si no sabe leer. La estampa presenta el cúmulo de características de espacio y vestimenta asociadas al tipo, lo cual lo visibilizaría en la calle ante otros y lo volvería afín a los pares, quienes podrían identificarse y sentirse parte de una colectividad. Las ilustraciones complementan el texto porque mediante la personificación aportan el contexto físico y cultural que los incluye. Veamos lo que sucede en las figuras siguientes:

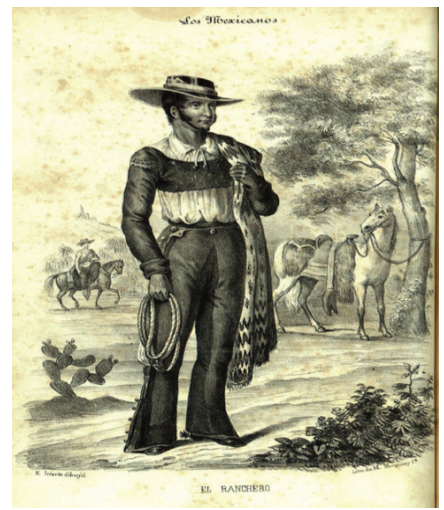

Figura 1. Litografía "El ranchero" de Hesiquio Iriarte, en Los mexicanos pintados por si mismos, Colección Digital UANL, 1854, pp. 190-1

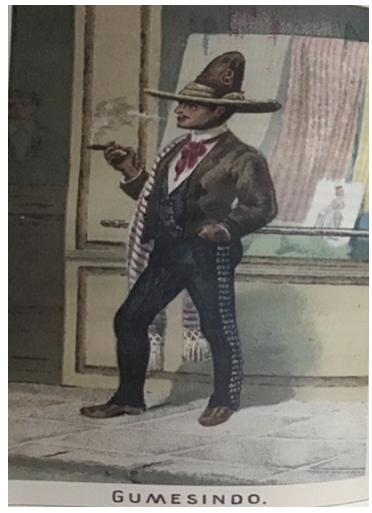

Figura 2. Cromolitografía sin firma que representa a "Gumesindo" en Los fuereños, UNAM, 2012, p. 166

Ambas pertenecen a la misma tradición de retratos de México y el mexicano, pero con diferentes funciones. A partir del género del retrato, los personajes están enmarcados en su entorno: el primero, en balance con él; mientras que el segundo, simulándolo. La tipología visual en la litografía de la izquierda y la cromolitografía de la derecha también funcionan como imágenes ejemplificadoras que, según Manuel Antonio Castiñeiras "al contrario de lo que sucede con la ilustración, este tipo de imágenes posee una alta autonomía 
de información con respecto al mensaje verbal que ejemplifica visualmente" (60). En ambas ilustraciones la disposición del espacio aprovecha la necesidad iconográfica del dibujante de colocar a los personajes en un espacio físico para complementar el planteamiento literario. Según Botrel:

tampoco puede el ilustrador representar exclusivamente retratos de personajes o personajes en pie y dejarlos, por decirlo así, en vilo; tiene que ponerles un marco, un entorno verosímil que suele ser muy realista y si quiere representarlos sentados tiene que acercarles una silla, un sillón, un taburete. (226)

Si bien hay casos en la tradición litográfica decimonónica mexicana del periodo y en la misma obra de Cuéllar ${ }^{18}$ donde los retratos son dibujados usualmente en fondos vacíos o apenas esbozados con marcas del crayón grueso sobre la piedra, sí corresponde al caso de Los fuereños, donde el par de momentos representados están iconográficamente anclados al espacio citadino por medio de la inclusión de elementos relacionados.

Estas precisiones del lugar no se mencionan en el texto, pero la imagen los recrea según los elementos que sugiera la narración. La lámina que acompaña al artículo costumbrista, dibujada por Hiriarte en 1854-1855 (ver Fig. 1), presenta al personaje íntegro al centro, rodeado de la flora del monte y cerca de un caballo ensillado que, por la presencia del jinete que aparece en el tercer plano de la litografía, se interpreta como analogía de la habilidad para controlar a la bestia; de igual forma que el lazo, que sostiene con la mano izquierda, se relaciona con la fuerza para domar el ganado y, con ello, todo su mundo. El retrato no corresponde a un momento específico de la crónica, sino a una representación general y alegórica del personaje. El protagonista está orgulloso en el espacio geográfico y moral que domina. Otros artistas plásticos destacados como el alemán

${ }^{18}$ Véase la litografía "Castaños" de la imprenta la Bohemia Literaria en el capítulo L de Obras VII. Narrativa VII. Las gentes que son así. UNAM, 2014, p.409. 
Carl Nebel (1802-55), el francés Edouard Pingret (1788-1875) y el mexicano Casimiro Castro (1826-1889) en diferentes momentos de la primera mitad del siglo XIX también elaboraron representaciones del personaje siguiendo estas pautas iconográficas.

La estampa de Gumesindo (ver Fig. 2), a la inversa, es presentada casi como la caricatura del tipo original. Si bien, la postura y el traje son similares, está inserto artificialmente en el contexto (según el paradigma marcado por el ejemplo anterior y seguramente también presente por experiencia cotidiana en el imaginario de los lectores) y, consciente o no de ello, lo disfruta. Aquí la estampa sí corresponde a un momento específico de la narración, el paseo de Gumesindo por las calles del centro de la ciudad. No obstante, a diferencia de la estampa de Hiriarte, que aparece junto a su texto, esta cromolitografía se ubica en las primeras páginas del libro junto a la información editorial. El lector tiene contacto con ella antes de comenzar la lectura. La altivez que pretende proyectar facialmente se confunde con la imitación de la pose de un pollo o lagartijo, según el propio texto, pero diferenciado por su atuendo campirano: "Gumesindo descollaba, entre los pollos vestidos de negro, por su sombrero canelo adornado con anchos galones de oro y por su pantalón de montar ajustado a la pierna" (198). La banqueta provee elementos cuya interpretación se basa, mas no se limita, a la novela corta, y que resaltan la condición de fuereño de Gumesindo: el aparador exhibe tipos de telas con las que su traje no se confeccionó, el figurín de modas muestra el atuendo de las mujeres que lo deslumbran y finalmente lo enamoran, por ser distintas de todas las que hubiera visto en provincia. Asimismo, y no referido por el texto, en el fondo aparece un hombre de frac asomándose, posible reflejo del afán de Gumesindo por mimetizarse con ellos, o pudiera ser su autopercepción, sostenida por una vanidad que, según la propia descripción literaria, "le decía que con eso [sus atractivos personales] le bastaba, y le parecía imposible que así como a él le habían gustado más de diez mujeres en menos de una hora, él, por de contado, bien podría hacer impresión en una o dos" (Cuéllar 198). De esta manera, su traje no representaría mayores complicaciones para triunfar en la empresa de enamorarse. 
Carlos Monsiváis señala la crítica social perenne en todo el proyecto de La linterna mágica contra el desequilibrado tránsito de la Ciudad de México hacia la modernización finisecular: "Cuéllar extrema su crítica a la vanidad, al juego de las superficialidades que para él denota la falta de educación que es la ausencia de propósitos en la vida" (19). A través de los comentarios de Gutiérrez las descripciones de las novedades tecnológicas ponen en entredicho la capacidad de la ciudad y sus habitantes para adaptarse al transporte, a las dinámicas culturales y en general a la vida moderna. Cuando explica a Don Trinidad el uso del tranvía, añade su aparente inutilidad como transporte ágil, pues solo abarca dos circuitos cruzados que ralentizan los trayectos en favor de los empresarios. ${ }^{19}$ Esta ironía sobre el manejo de la vialidad se suma a otros comentarios sobre la desafortunada situación del escaso mantenimiento e higiene de las plazas públicas o la visibilidad de las calles prostibularias. Lo anterior, visto a partir de la cromolitografía, justificaría que el ranchero en la ciudad se ridiculice al participar de la dinámica superficial que apenas sostienen las clases acomodadas que asisten a la nueva oferta cultural europea ${ }^{20}$ en comparación con la solemnidad de su imagen precursora de 1855 que trataba de mostrar plástica y narrativamente el orgullo por la vida en el campo. En este sentido, el joven ranchero es el mejor ejemplo del contraste entre la familia fuereña y los capitalinos, por lo que se le dedica no solo el retrato

19 “_Entonces cómo se explica V. ese rodeo?

-Es muy sencillo. Ya hemos dicho que en otras partes el plano de las tranvías lo traza el municipio para bien de la población. En México traza el plano el mismo empresario para resolver un problema a todas luces favorable a sus intereses, aunque molesto para el público ... Lo más acertado, pues, para la empresa, fue extender sus circuitos de tal manera que abarcasen la area de la ciudad, para no dejar lugar a nuevas empresas. Así el empresario monopoliza el servicio, y el público, que no se ocupa de hacer comparaciones, está muy ufano con tener tranvías, y como va sentado le parece muy divertido eso de hacer números 8 por sólo seis centavos" (20-21).

${ }^{20}$ Gutiérrez relata cómo las compañías teatrales mexicanas coexisten con las extranjeras, lo que ocasionaría pérdidas económicas para los primeros. 
inicial de la edición española de 1890, sino también la cromolitografía pegada en la portada del ejemplar (ver Fig. 3).

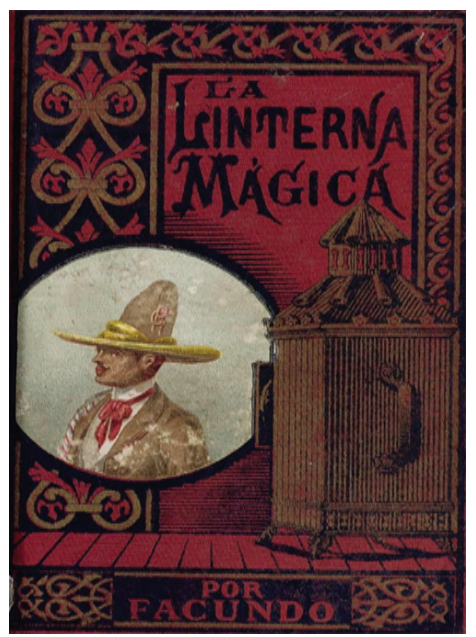

Figura 3. Portada de La Linterna Mágica, de José Tomás de Cuéllar o Facundo, con cromolitografía (sin firma) que representa a Gumesindo.

Biblioteca Digital Hispánica, 1890.

La estampa es una versión de plano medio corto del retrato de Gumesindo dibujada específicamente para ser la parte "alumbrada" por la linterna. La insistencia editorial por mostrarlo constantemente lo vuelve el personaje más valioso para ser observado en su arco narrativo. Tanto su imagen completa como el texto equivalen a una construcción satírica del campirano cauteloso ante los peligros de la ciudad, que ahora se deja arrastrar por ella.

Respecto a la estructura del artículo costumbrista de José María Rivera, María Esther Pérez Salas apunta que "dicha relación permitió al autor [José María Rivera] describir los diferentes modos de vida entre la ciudad y el campo, y los peligros que cada uno presentaba, sobre todo cuando el personaje incursionaba en el medio ajeno" (Costumbrismo... 292). La ciudad se asocia para los personajes de Rivera y de Cuéllar con la educación (recelosa, pero se admite la posibilidad de acceder a ella) y el ocio; mientras que el campo se asocia al trabajo y la ignorancia. La identidad tipificada del ranchero se diluye 
en la modernidad citadina. El carácter franco, dadivoso y hasta bronco que lo caracteriza se vuelve inocencia a merced de los pícaros:
$[\mathrm{N}]$ o obstante que es el único de los jóvenes fuereños que no intenta mimetizarse físicamente con la urbe, también sufrirá las consecuencias de construir en la idílica provincia una ima- gen de la Ciudad de los Palacios, en consonancia con sus an- helos amorosos, así como de mostrarse en ese espacio como un ingenuo charrito ansioso de aventuras, pero que ignora las dinámicas sociales de la fauna capitalina. (Zavala, "Espejis- mos..."19)

La representación nacionalista de la estampa de 1855 se desprecia porque el texto dota a los personajes de un limitado albedrío más allá de su carácter tipificado. No obstante, salir de su configuración modélica los desprotege ante sus propios impulsos guiados por la búsqueda de la satisfacción del deseo, móvil de sus acciones. Gumesindo y su hermana Clara creen encontrar la idealización de pareja y ambos son burlados por sus amantes: Clara cede ante la seducción de Manuel, y Gumesindo pierde dinero y salud en el burdel donde se reúne con Luisa, a quien confunde con una señora elegante. El deseo mueve a los personajes, pero nubla su visión y los pierde al desviarlos de los códigos morales que debían regirlos.

La segunda ilustración de la novela corta, con base en la edición de 1890 , es una litografía a plumilla con $t i t u l i^{21}$ que aparece a la mitad del capítulo XVI (ver Fig. 4). Narra visualmente el pasaje cuando Gumesindo es descubierto por Don Trinidad y Doña Candelaria, sus padres, al interior de la casa de su amante Luisa en la $1^{\text {a }}$ calle de Plateros luego de frecuentarla durante días. Posteriormente, la policía lo arresta debido a un escándalo suscitado dentro que involucró varios disparos. Por una confusión digna de una comedia de enredos, el matrimonio Ramírez también es llevado por la policía:

21 "Consiste en una palabra o frase simple que acompaña a la figuración para identificarla o aclarar su contenido" (Castiñeiras 61). 
La escena del tumulto anterior había tomado un carácter de solemnidad y de silencio al emprender la marcha hacia la inspección de policía; la comitiva desfilaba en este orden: iba por delante Gumesindo, custodiado por un guarda, pistola en mano. Seguía don Trinidad al lado de otro guarda; después el joven desconocido. En seguida dos mujeres vestidas de blanco que levantaban sus largos vestidos dejando ver su calzado de baile; llevaban salidas de teatro ${ }^{22}$ en la cabeza, y por último, doña Candelaria entre un guarda y aquel señor curioso que le había ofrecido su protección. (Cuéllar 266)

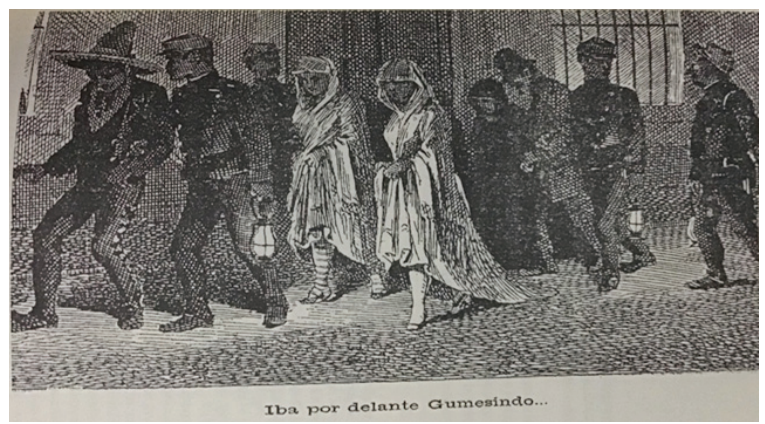

Figura 4. "Iba por delante Gumesindo", grabado de Los fuereños, de José Tomás de Cuéllar, UANL, 1890, p. 151.

El hecho de que sea la última estampa y corresponda al momento culminante de la deshonra supone una recapitulación del conflicto de la obra. El desfile de los personajes ilustra cómo la torpeza y el apasionamiento de unos, como Gumesindo y sus hermanas; y la ingenuidad de otros, como Don Trinidad y Doña Candelaria, provoca que sean arrastrados a los bajos fondos. La inocencia fuereña evitó

${ }^{22}$ De acuerdo al Diccionario de la Real Academia de la Lengua Española, es un "[a]brigo ligero que usan las señoras para cubrirse el vestido que llevan al teatro". Estos mantones, que podían ser de distintas telas, eran el equivalente femenino de la capa para las señoras de estatus social elevado. 
que desarrollaran suficiente malicia para escudarse de los peligros de la urbe y de cualquier otro entorno ajeno a sus costumbres. Cabe resaltar que, al contrario que en la descripción literaria, la estampa muestra a Gumesindo al frente y, detrás suyo, a un par de mujeres vestidas de blanco, presumiblemente las prostitutas al ser las únicas en la imagen que exhiben sus piernas, seguidas por Doña Candelaria, de color oscuro, cubierta completamente junto a su esposo. La solemnidad que mencionó Cuéllar se adapta por la composición pictórica como una escena lúgubre que transcurre en la oscuridad, apenas iluminada por los candiles que cargan los gendarmes y la luz que emana de las ventanas. Al igual que en la estampa "Gumesindo", aparece un rostro anónimo asomándose a la izquierda del fondo de la estampa, cual ojo público que además de situar visualmente que la procesión camina por la banqueta, reafirma la exposición al escarnio social.

Gracias a la incorporación del retrato cromolitográfico es posible establecer una transición visual del personaje: en las dos primeras se le muestra rozagante y confiado; mientras que en la litografía a pluma está reducido a sombras, enredado en tumultos y denigrado a la cabeza de la procesión policiaca. En este diálogo entre imagen y texto el antecedente visual es la litografía El ranchero, de Hesiquio Iriarte. Se le reconoce en el grabado por los mismos elementos composicionales que en la cromolitografía: su traje y su sombrero.

\section{Crítica a partir de personajes tipo}

El diálogo establecido por Cuéllar con la tradición costumbrista precede la publicación de Los fuereños y no se limita a la revisión de las colecciones de tipos. Desde la puesta en escena de Naturaly figura (1864), hasta el inicio y desarrollo de su novelística como la obra por entregas El pecado del siglo. Novela histórica [Época de Revillagigedo-1789] (1869) o Ensalada de Pollos. Novela de estos tiempos que corren tomada del "carnet" de Facundo (1869-1870), Historia de Chucho el Ninfo (1871) y Las gentes que son así (1872), el autor empleó su escritura para externar una crítica al funcionamiento de la sociedad mexicana 
ante los cambios del contexto político, social y cultural. Asimismo, la usó para describir sus costumbres y señalar sus problemas, principalmente la falta de educación y la ascendiente frivolidad de la clase media, ${ }^{23}$ temas estructurales de sus textos. El empleo de los tipos populares como el ranchero, los criados y los lagartijos, entre otros, le permitió a lo largo de su trayectoria presentar comportamientos concretos mediante personajes con características fácilmente reconocibles, práctica que mezclada a su estilo directo y cómico se acercaría a los lectores en forma de "contraejemplos" (Zavala, "Prólogo" 13) para erradicar las actitudes restringentes del progreso del ciudadano mexicano. Asimismo, la obra facundiana recibió buenas críticas por parte de Guillemo Prieto e Ignacio Manuel Altamirano "quienes elogiaron la habilidad del narrador para recrear el entorno nacional" (Zavala, "Prólogo" 11), lo cual demuestra que su propuesta formativa no solo era aceptada, sino congruente con los postulados éticos en boga entre tales autores y otros del periodo.

La exploración del realismo nacionalista de la segunda mitad del siglo XIX en la obra de Cuéllar, aún cercana al costumbrismo, tampoco terminó con Los fuereños (1883), pues otras publicaciones, como la destacada Baile y Cochino... (1885) continuaron por esta vía. De igual forma, la preocupación estética de Facundo se mantuvo cercana permanentemente a la plástica, pues la inclusión de imágenes fue una práctica constante en sus proyectos editoriales, tanto en La linterna mágica, como en la revista La Ilustración Potosina. Semanario de Literatura, Poesía, Novelas, Noticias, Descubrimientos, Variedades y Avisos, 1869 o incluso en las publicaciones periódicas como la que aquí se ha estudiado. Esto permite reafirmar la pertinencia del escrutinio a partir del contraste con Los mexicanos pintados por si mismos, tradi-

23 "La mayor parte de sus producciones se dirigían a la emergente clase media capitalina, así como a las altas esferas de la comunidad nacional. . . A través de ellos [los tipos] le fue posible recrear críticamente el comportamiento de estos grupos, considerados por Facundo como los principales responsables de lograr la consolidación y el progreso de México en tanto nación independiente. Siempre con ironía y cierto humor negro, se propuso así, retratarlos a la luz de su linterna" (Zavala, "Prólogo" 9). 
ción textual con la que es enlazable genealógicamente la narrativa de Cuéllar y editorialmente mediante el uso de imágenes.

Bajo este panorama, tipificar a Gumesindo puede entenderse como una pieza del gran proyecto de escritura formativa compuesta por la totalidad de la obra facundiana donde, como se afirmó antes, hubo anteriormente otros charros que experimentaron un cambio degradante. La popularidad con la que contaba de antemano el tipo del ranchero le permite ser una presa ejemplar de la degradación que acecha a los ciudadanos inocuos. La advertencia por la caricaturización y el fin trágico del personaje no es aplicable solo para otros rancheros; alcanza a toda la población impresionable por las novedades tecnológicas, estéticas e infraestructurales, que no entienden los nuevos códigos de conducta que estos cambios conllevan y se amoldan a ellos con torpeza.

Para Vicente Quirarte, Cuéllar retoma la tradición de los cuadros de costumbres y el dibujo de los tipos populares, pero los innova tanto en aspectos formales, en cuanto que sus personajes actúan enlazados por el vínculo de la trama narrativa, como en el proceso metódico de estudiarlos y rastrear su genealogía (36). Asimismo, cabe añadir que los personajes eligen por sí mismos cambiar su comportamiento, aunque influidos por el ambiente. Gumesindo, el ranchero o "charrito", como también se le define en la obra, se mueve conforme a su búsqueda personal de amor y novedad, hasta que los excesos lo vencen. La integridad que define sus modelos tipificados previos se deja de lado por adoptar nuevas libertades y placeres, influidos por la reciente oferta cultural y tecnológica que llegaba al país. Sin embargo, estas satisfacciones se alejan del trabajo y la familia, y por ello conducen irremediablemente al declive emocional y físico:

No había podido apreciar hasta hoy la tranquilidad que se disfruta en medio de las costumbres sencillas, como tampoco había podido figurarme hasta dónde pueden llegar los peligros del lujo y la prostitución de las grandes ciudades. Ya usted lo ve, señor Gutiérrez, Gumesindo era bueno, sencillo, sobrio y honrado. Me lo llevo enfermo, de una enfermedad 
que acaso no alcanzaría a curarle ya ni el campo ni el trabajo. (Cuéllar 283-84)

La última litografía sintetiza textual y pictóricamente a los fuereños como extraños, ingenuos y derrotados. En la estampa también aparecen un lagartijo y las prostitutas, actores sociales cuya degradación puede considerarse como parte intrínseca de la propia ciudad. Sin embargo, para la honesta familia de provincia, la humillación representa el fin de su tranquilidad, su orgullo y estabilidad familiar, tres de los aspectos pendulares de la vida del ranchero que defendía José María Rivera con mayor vehemencia en 1855.

El ciclo del ranchero en Los fuereños, iniciado textual y visualmente con su definición tipificada, termina en el mismo punto en ambos discursos: con la disolución de su imagen. Al final del texto, el propio padre asevera tristemente que el daño de su hijo será irreversible. La desgracia les permite apreciar la tranquilidad que tuvieron mientras su vida fue sencilla en el campo.

La litografía aprovecha la texturización de las marcas de la pluma para oscurecer a Gumesindo, reduciéndolo a una silueta lúgubre en el cortejo, donde el resto de las figuras también aparecen difusas u ocultas entre los policías y su vergüenza. La procesión de los personajes es comparable visualmente con una danza de la muerte, pues la universalidad del trance mortuorio arrastra consigo a todos los personajes, mezclados sin distinción estamental o moral. ${ }^{24}$ Los policías simbolizarían las alegorías de la muerte o muertos que conducen a todos, mientras que la deshonra es el tránsito hacia el fin de la vida, pues la escena también se plantea como parte de un cortejo fúnebre; ambos casos indican la muerte social.

24 “En la mentalidad de la Baja Edad Media predominan tres puntos de vista sobre la percepción de la muerte. Todos ellos confluyen en la Danza Macabra y ayudan a comprenderla. El primero ve la muerte como un fenómeno universal, que puede sobrevenir de forma brusca e inesperada a personas de cualquier edad y condición, sin tomar en cuenta su estatus social o económico” (González 25). 
El realismo literario de la novela facundiana aspira a mostrar de manera objetiva los sucesos de la vida humana. El amor es una pasión más y no el centro de la existencia donde el dinero es bien de mayor valor. Sus personajes son los tipos porque son modelos para representar a toda una clase social (Mata 103). De igual forma, la imagen refuerza este realismo desde su técnica y estilo, el cual pudo tener por resultado una evidenciación y acentuación del realismo —un como "exceso de realidad" (Botrel 228)—. Cuéllar expone las leyes que determinan la sociedad de la Ciudad de México a finales del siglo XIX, y con ello, visto desde el destino de sus personajes, concluye que del proyecto del ciudadano en formación que representaban los tipos populares de las décadas pasadas, solo queda la imagen nostálgica del intento de caracterizar al mexicano como ser pícaro y rudo, pero bueno y firme en el interior. Dichos atributos son inútiles sin la malicia para entender las dinámicas sociales de la nueva urbe. Como afirmó Don Trinidad al principio de la obra, "A este quítelo usted de lazar y andar a caballo y no sabe hacer nada" (176).

\section{Conclusiones}

En suma, Gumesindo es la actualización del tipo popular mexicano retratado en la década de 1850 . Pierde la solemnidad del hombre de campo y se caricaturiza textualmente, con base en el tratamiento burlesco de los rasgos identitarios del personaje. El ranchero se configuró tradicionalmente como un hombre centrado en sus labores de la tierra, con una relación ambigua y esencialmente económica con la ciudad, debido al recelo mutuo ante la actitud y costumbres del otro. El sujeto citadino y el rural se veían uno al otro con desconfianza, por la soberbia del primero y la ingenuidad provinciana del segundo.

Es por ello que en los albores de la modernidad, durante la búsqueda de apertura y expansión cosmopolita a un ritmo similar al de las capitales europeas, llegó a considerarse que este emblema del campo y de la masculinidad mexicana tradicional — hasta la actuali- 
dad - posiblemente fuera un anclaje anticuado al pasado de un país esencialmente campirano a lo largo de la centuria decimonónica. Esto podría haber dado pauta para retomarlo visual y éticamente en este momento de la década de 1880, desde una perspectiva revisionista, para contrastarlo con el devenir social en un entramado narrativo que roza lo paródico. Sin embargo, pese a la aparición de otro ranchero vicioso en Las gentes que son así, no considero que tal tinte paródico indique una predisposición negativa del autor hacia esta figura representativa, sino que responde a una tradición caricaturesca en ascenso visible en otros soportes artísticos, como las representaciones gráficas irónicas del ranchero revolucionario en las calaveras de pliegos de cordel.

La obra corrobora, en el marco del realismo literario, que la familia de fuereños representa la actitud impresionable de quienes por primera vez se enfrentan a los cambios en costumbres, valores, tecnología e infraestructura traídos por la "modernidad". Los Ramírez, compuestos por diferentes personajes tipificados de la escena literaria en general y en la propuesta narrativa de Cuéllar en particular, modificaron su dinámica social por tratar — sin éxitode adaptarse al comportamiento capitalino. Asimismo, agrupados pueden verse como un solo tipo en sí mismo: los fuereños.

Desde una postura crítica a las conductas "inmorales" de la ciudad moderna, la desgracia que se cierne sobre cada uno de los integrantes de la familia Ramírez se debe a su propia sed de placeres; al saciarla renunciaron a costumbres y valores de su vida provinciana. Desde la tipificación son capaces de leer el mundo solo desde la predeterminación de su origen social. La movilidad que les permitió el supuesto "libre albedrío" les resultó perjudicial. Su otredad no se limita a su procedencia rural, sino también a representar lo opuesto de los valores de la vanidad, el ocio, el vicio y la simulación que ahora preponderan en la urbe y modelan sus nuevas costumbres. Para Manuel de Ezcurdia,

La incisiva y desesperada visión que tiene Cuéllar de México y de los mexicanos, de las condiciones urbanas de su capital, ... su rechazo de lo autóctono, esta crítica que él debió conside- 
rar "sana" ya que se ocupó de dar las prescripciones necesarias, son giros "inoportunos" en el desierto de complacencia de la sociedad mexicana que sabía leer en el siglo XIX . . (64)

No hay un énfasis en una representación regional específica porque no es necesario, desde la óptica del lector puede ser cualquier fuereño. El objetivo de la trama es contrastar uno y otro estilo de vida.

No hay otros tipos presentados visualmente de forma exhaustiva en la novela, mas la configuración textual de Los fuereños enfatiza la descripción plástica. Los tipos se conforman mediante la adaptación de esquemas previos, donde su léxico y vestimenta están predeterminados por su genealogía. Su recuperación también permite desacralizarlos, apartarlos de la versión solemne y moralizante que trató de establecerse en la década de 1850 cuando apareció Los mexicanos pintados por sí mismos. Su acartonamiento anterior, en el cuadro costumbrista, se rompe al desenvolver los tipos en un ambiente narrativo heterogéneo. De igual manera, la imagen configura visualmente a quienes muestra y marca dos momentos narrativos esenciales: la presentación y la degradación del ranchero.

La compenetración y diálogo entre los discursos textual y visual contribuye a formular varias críticas: una contra la pérdida de las costumbres mexicanas en favor de imitar usos extranjeros y otra sobre la inadaptación que condena a quienes son extraños en este mundo moderno. La insatisfacción de las expectativas del fuereño reside en su incompatibilidad con el tiempo-espacio que se cierra a la imitación europea, donde los elementos antes vanagloriados como "nacionales" no han perdido visibilidad, pero sí vigencia modélica.

Las diferencias composicionales entre la representación literaria del tipo popular en las dos publicaciones aquí estudiadas, apoyada por el discurso visual de las litografías, refuncionalizan al ranchero desde su aparición en las colecciones de tipos previas a 1883 hasta el tratamiento paródico de Cuéllar de los valores que este encarnaba. Asimismo, Los fuereños coincide con el afán didáctico de las publicaciones mexicanas e hispanoamericanas decimonónicas que buscaban la formación de lectores. La ilustración litográfica también es una guía de lectura que contribuye a expandir los márgenes de la in- 
terpretación del lector, pues las estampas pueden inspirar tanto burla como lástima ante los incidentes desafortunados de Gumesindo.

La degradación de Gumesindo no solo es la de un personaje concreto, sino la de una imagen pictórica identificable y asumible como "propia" y "nacional" que, a pesar de vivir en el imaginario con dignidad, ahora es humillada. Sin embargo, esto se aleja de la añoranza nostálgica por un pasado glorioso. Para Cuéllar, en los albores del porfiriato durante el cuatrienio de Manuel González entre 1880 y 1884, el problema reside en optar por máscaras cosmopolitas sin atender primero el espacio moral y social donde habrían de lucirse, convirtiendo a la ciudad y sus habitantes en revisiones caricaturescas de sí mismos.

\section{Bibliografía}

Arellano Vázquez, Lucila. “Análisis de las portadas impresas en México de 1820 hasta 1845: una visión del sector editorial a través de los libros y sus portadas". Tesis, Universitat de Barcelona, 2007.

“Boletín Bibliográfico”. El Nacional, 30 de mayo de 1889, p. 2.

Botrel, Jean François. "Imágenes para leer y para ver: La ilustración de las novelas realistas españolas". O século do romance Realismo e Naturalismo na fição oitocentista, Coimbra, Centro de Literatura Portuguesa, coordinado por António Apolinário et al., Centro de Literatura Portuguesa, 2013, pp. 223-240.

Castiñeiras González, Manuel Antonio. Introducción al método iconográfico. Ariel, 2005.

Cuéllar, José Tomás de. Los fuereños. La Linterna Mágica. Segunda Época. Colección de novelas de costumbres mexicanas, artículos y poesías. Tomo VII, Imprenta y Litografía de "El Atlántico", 1890, Colección de la Biblioteca Digital Hispánica.

- Los fuereños. La linterna mágica: colección de novelistas de costumbres mexicanas, articulos y poesías. Tomo VII, Imprenta y Litografía de "El Atlántico", 1890, pp. 7-187, Colección Digital Universidad Autónoma de Nuevo León, http://cdigital.dgb.uanl.mx/ la/1080046422_C/1080046422_C.html 
. Los fuereños. Obras IV. Narrativa IV. Novelas cortas, Universidad Nacional Autónoma de México, 2012, pp.166-284.

Diccionario de la lengua española. Versión 23.3 en línea, 24 de febrero de 2020, dle.rae.es/salida\#FD1Kzsp

Ezcurdia, Manuel de. "Modernidad de Cuéllar". Del fistol a la linterna. Homenaje a José Tomás de Cuéllar y Manuel Payno en el centenario de su muerte, Universidad Nacional Autónoma de México, 1997, pp.59-68.

Frías y Soto, Hilarión, et al. Los mexicanos pintados por si mismos. Tipos y costumbres nacionales. Miguel Ángel Porrúa, 2011.

- Los mexicanos pintados por si mismos. Tipos y costumbres nacionales. Imprenta de Manuel Murguía, 1854-1855, Colección Digital UANL, cdigital.dgb.uanl.mx/la/1020001188/1020001188.html? fbclid=IwAR1-QUgCUKBN2el2klIWGRIRE8SMNg7n0NLBxEubnaH-_8ObsumoQJSbw2c

Fróes Da Fonseca, María Rachel. "La vulgarización científica en México: "La leyenda ó novelita" de José Joaquín Arriaga (18311896)". Revista Inclusiones, vol. 5, no. 4, octubre-diciembre, 2018, pp. 31-46

Genette, Gérard. Palimpsestos. Traducido por Celia Fernández Prieto, Taurus, 1989.

González Zylma, Herbert. "La danza macabra". Revista Digital de Iconografía Medieval, vol. VI, no. 11, 2014, pp.23-51.

Mata, Oscar. La novela corta mexicana en el siglo XIX. UNAM, 2003.

Mitchell, W.J.T. Teoría de la imagen. Ensayos sobre representación verbal y visual. AKAL / The University Press of Chicago, 1994.

Monsiváis, Carlos. "Las costumbres avanzan entre regaños". Del fistol a la linterna. Homenaje a José Tomás de Cuéllary Manuel Payno en el centenario de su muerte, UNAM, 1997, pp.13-22.

Pas, Hernán. "Leer (con) imágenes. Litografías y prensa periódica en los procesos de lectura y escritura a mediados del siglo XIX en el Río de la Plata". Tramas impresas. Publicaciones periódicas argentinas (XIX-XX), coordinado por Verónica Delgado, Alejandra Mailhe y Geraldine Rogers, Universidad Nacional de La Plata, 2014, pp. 64-79. 
Pérez Salas Cantú, María Esther. "Primeros intentos por definir los tipos mexicanos en la primera mitad del siglo XIX". Histoire(s) de l'Amérique latine, vol. 1, 2005, pp.1-10.

. Costumbrismo y litografía en México: Un nuevo modo de ver. UNAM, 2005.

Quirarte, Vicente. "Usos ciudadanos de José Tomás de Cuéllar". Del fistol a la linterna. Homenaje a José Tomás de Cuéllar y Manuel Payno en el centenario de su muerte, coordinado por Margo Glantz, UNAM, 1997, pp.29-40.

Ramos Bautista, Gretel y Belem Clark de Lara. "Advertencia editorial". Obras VII. Narrativa VII. Las gentes que son así, de José Tomás de Cuéllar, UNAM, 2014, pp.11-32.

Rivera, José María. "El ranchero". Los mexicanos pintados por si mismos, de Hilarión Frías y Soto, pp.191-205.

Skerritt Gardner, David. "Rancheros y capas medias en la historia de México: Unas reflexiones". Anuario. Centro de Investigaciones Históricas. Instituto de Investigaciones Humanisticas. Universidad Veracruqana, vol. VII, 1990, p. 131-145.

Zavala, Ana Laura. "Espejismos de la modernidad: la Ciudad de México en Los fuereños de José Tomás de Cuéllar", Literatura Mexicana, vol. XXVII, no. 2, 2016, pp.9-30.

. "Más allá de la linterna mágica: Baile y cocbino... (1885), de José Tomás de Cuéllar". Literatura y prensa periódica mexicana. Siglo XIX y XX. Afinidades, simpatias comlicidades, coordinado por Marco Antonio Chavarín González e Yliana Rodríguez González, Colegio de San Luis / Universidad Nacional Autónoma de México, 2017, pp.103-127.

. "Prólogo". Historia de Chucho el Ninfo y Los fuereños, de José Tomás de Cuéllar, Penguin Random House / Grupo Editorial México, 2017, pp. 2-19. 